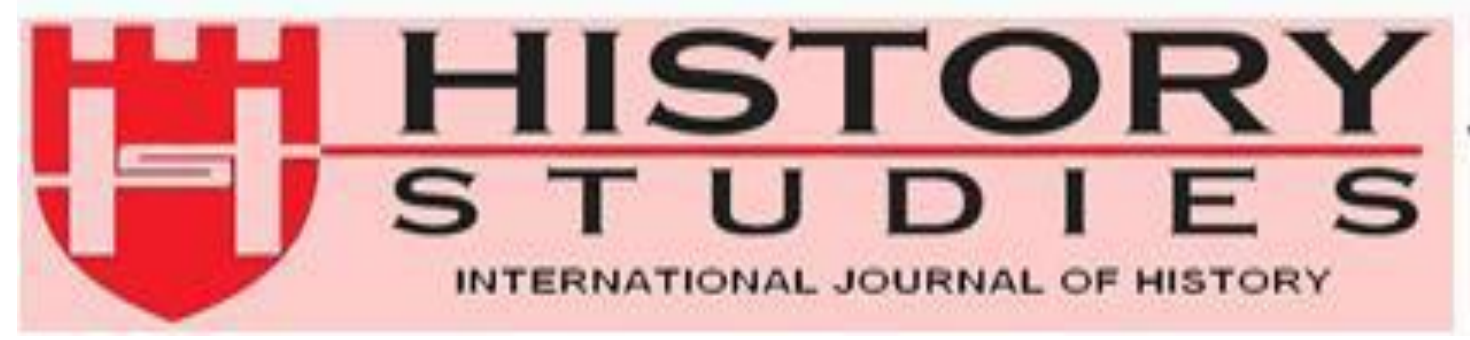

ISSN: 13094173 (Online) 1309 - 4688 (Print)

Volume 6 Issue 6, p. 165-182, December 2014

\title{
VI. Dönem TBMM'nin Toplanması ve Genel Yapısının Analizi
}

An Analysis of the 6th Turkish Parliament and Its General Structure

\author{
Okutman Sibel Küçükkülahlı \\ Düzce Üniversitesi - Düzce \\ Yrd. Doç. Dr. Fatih Özçelik \\ Düzce Üniversitesi - Düzce
}

\begin{abstract}
Öz: Bu çalışma 1939 yılında seçilen VI. Dönem TBMM'nin sosyal-kültürel yapısını ve hükümet programlarını inceleyerek, bu dönemde görev alan Refik Saydam ve Şükrü Saraçoğlu Hükümetleri’nin iç ve dıs politikanın tatbiki konusunda daha önceki hükümetlerden ve birbirlerinden farklı uygulamaları olmadı̆̆ını tespit etmektedir. Ayrıca bu dönemde TBMM'ye seçilen kadın vekillerin tamamının devlet memurluğundan geliyor olması siyasetin henüz kadınlar arasında tam olarak yayılamadığın göstermektedir.
\end{abstract}

Anahtar Kelimeler: TBMM, Türkiye Büyük Millet Meclisi, Türkiye Cumhuriyeti, Milletvekili

Abstract: This study examines the socio-cultural structure of the 6th Turkish Parliament, elected in 1939, along with the government programs and presents that the domestic and foreign policies of the Refik Saydam and Sukru Saracoglu governments were not different from earlier governments. Furthermore, the fact that all elected women in this period were from the ranks of state bureaucracy shows that politics had yet to be largely embraced by women.

His tory

Studies

Volume 6

Issue 6

December

2014

Keywords: Turkey, Turkish Parliament, Turkish Republic, Parliament Members

\section{Giriş}

23 Nisan 1920 Cuma günü yurdun her yanından seçilmiş milletvekillerinin katılımıyla Ankara'da açılan Türkiye Büyük Millet Meclisi'nin siyasal sistem içerisindeki yeri ve önemi, tüm çağdaş siyasal sistemlerde olduğu gibi yasama, kural koyma, temsil, eğitim, denetim ve araştırma gibi işlevleri yerine getirmesinden kaynaklanmaktadır. Ancak yasamanın tüm bu işlevleri tek partili ya da çok partili sistemlerde uygulama alanları olarak farklılık göstermektedir. Tek Partili dönemde seçim, parti üst yönetimince belirlenen adayların müntehib-i sani denilen ikinci seçmenlerce onaylanması anlamını taşıyor ve demokrasi açısından çok da işlevsel bir yer tutmuyordu. Parti tüzüğüne sikı sikıya bağlı milletvekillerinden oluşan parlamentoda, ağırlıklı meslek grubu resmi görevlilerden oluşuyordu. Tek Parti döneminde meclis, faaliyetleri ve çalışmaları açısından parti kararlarına bağlı bir organ gibi çalışarak, adeta CHP'de alınan kararları meşrulaştırma işlevi görmüştür. $\mathrm{Bu}$ nedenle 1924 anayasasıyla yasama organına tanınan üstünlük, yürütmenin yasama üzerindeki etkisi nedeniyle kullanılamamıştır. ${ }^{1}$

\footnotetext{
${ }^{1}$ Esat Öz, Tek Parti Yönetimi ve Siyasal Katılım (1923-1945), Gündoğan Yayınevi, Ankara, s. 164-166, Yunus Nadi, 1939 yılında, Cumhuriyet gazetesinde yer alan köşesinde "Bizde TBMM'nin teşrii salahiyet ve icrai kuvvetlerin kaffesini kendisinde toplayan bir müessesedir. Cumhur reisini meclis seçer ve erkanı ancak kendi azası arasından çıkabilen hükümetini meclis daima gözü önünde bulundurur. Meclisin beğenmediği hükümet yerinde duramaz, derhal yerine yenisi kurulur" (Yunus Nadi, Baş makale, Cumhuriyet, 24 Mart 1939,) dese de parlamentonun Tek Parti döneminde pek etkin olduğu söylenemez. Bunun nedeni de Cumhuriyetin ilk y1llarında, dönemin kendine özgü nitelikleridir. Ancak Türkiye Büyük Millet Meclisi her zaman rejimin kalbi olma özelliğini
} 
Türkiye'de tek parti yönetimi dönemin koşulları nedeniyle Atatürk döneminde uygulanmış, onun ölümünden sonraki dönemde 1945 'e kadar İsmet İnönü yönetiminde devam etmiştir. Atatürk'ün ölümünden sonra gerçekleştirilen ilk genel seçim çalışma konumuzda olan 1939 seçimleri olmuştur. Bu seçimlerde de tıpkı diğer seçimlerde olduğu gibi İntihab-1 Mebusan Kanun-1 Muvakkatı'na göre düzenlenmiştir. Bu kanun 2 Ağustos 1908 tarihinde kabul edilmiştir. 1908, 1912, 1914, 1919, 1923, 1927, 1931, 1935, 1939 seçimleri, 6 defa değişikliğe uğrayan, toplam 83 maddeden oluşan bu kanuna göre yapılmıştır. ${ }^{2}$

Bütün yurtta 15 Mart 1939 Çarşamba günü başlayan ikinci müntehip seçimleri 21 Mart 1939 akşamı her tarafta sona ermiş ve bütün vatandaşlar oylarını Cumhuriyet Halk Partisi'nin gösterdiği adaylara vermişlerdir. 62 vilâyetin ikinci müntehip yekûnu 40.979'dur. Vilâyetlerde ikinci müntehip seçimine iştirak nispeti \% 77.82'dir. Yurdun birçok yerlerinde şiddetli bir kışın hüküm sürmesine rağmen katılım oldukça yüksek olmuştur. ${ }^{3}$ Milletvekili aday listelerinin İsmet İnönü tarafından 24 Mart 1939 tarihinde ilan edileceği ve aynı akşam radyolarda okunacağı bildirilmiştir. Daha önce Malatya milletvekili olan milli şef İsmet İnönü Ankara'dan aday gösterilmiştir. Yine aynı seçimlerde azınlıklardan da aday seçilmiş, kadın milletvekilleri ${ }^{4}$ ile müstakil grubun sayısı bir miktar arttırılmıştır. ${ }^{5}$

Cumhuriyet Gazetesi'nin 25 Mart 1939 tarihli nüshasında da neşredilen "İnönü'nün Beyannameleri" başlığı altında Millî Şef İsmet İnönü'nün aşağıdaki beyanatına yer verilmiştir:

\section{Sevgili Vatandaşlarım!}

Büyük Millet Meclisi'ni teşkil edecek yeni namzetleri huzurunuza takdim ediyorum. Bu namzetleri intihap ederken bize yalnı vazifemizin vicdanı ilcası ile vatandaşlarımızın temayülü rehber olmuştur. Asîl milletimizin büyük Meclis azaları üzerindeki itimadının derecesini anlayabilmek için, Parti teşkilâtında ve halk tabakaları arasında çok dikkatli tetkikler yaptık; memleketin geniş mintıkalarında Partiye mensup ikinci müntehiplerin takdir ve tavsiyeleri demek olan istişare reylerine müracaat ettik. Katî namzetleri yüksek reyinize arz ederken vatanın mukadderatına dört sene müddetle hâkim olacak mebuslar

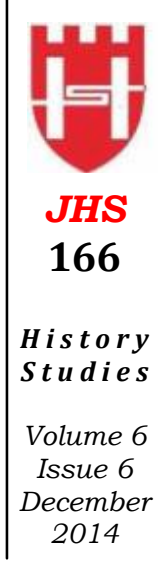

de muhafaza etmeyi başarmıştır. Yüksel Polat, XV. Dönem Türkiye Büyük Millet Meclisi(1973-1977), (Hacettepe Üniversitesi, Atatürk İlkeleri ve İnkılap Tarihi Enstitüsü, Yayımlanmamış Yüksek Lisans Tezi), İstanbul 2006, s. 2.

2 İntihab-1 Mebusan Kanun-1 Muvakkatı Seçim kanunu, padişah iradesiyle 2 Ağustos 1908 yılında çıkarılmıştır. 83 maddeden oluşan kanun, seçimlerin iki dereceli olarak ve çoğunluk sistemiyle yapılmasını içermektedir. İki dereceli seçim sisteminde seçmenler (müntehib-i evvel) ikinci seçmenleri (müntehib-i sani) belirliyordu. Mebusları seçenler bu ikinci seçmenlerdir. Kanuna göre birinci ve ikinci seçmenlerde vergi ödeme ve 25 yaşını doldurmuş olma koşulu aranmaktadır. Yine kanuna göre her sancak bir seçim çevresi kabul edilmekte ve her 50.000 erkek seçmen için bir mebus seçilmesi esası kabul edilmiştir. Erol Tuncer, Osmanlı'dan Günümüze Seçimler (1877 - 1999), Toplumsal Ekonomik Siyasal Araştırmalar Vakfi, Ankara 2002, s. 21-22, 26.

3 İsmet Binark, Türk Parlamento Tarihi (TBMM VI: Dönem 3 Nisan 1939 - 15 Ocak 1943), Türkiye Büyük Millet Meclisi Vakfi Yayınları, Ankara 2006, s. 39.

${ }^{4}$ Kadınlara seçme ve seçilme hakkının tanınmasıyla İntihab-1 Kanun-1 Muvakkatı’nda 22 Aralık 1934 tarih ve 2631 sayılı kanunla, 3 Nisan 1923 tarihli ve 320 sayılı kanunun 5. maddesinde iki önemli değişiklik yapılmıştır. Kadınlara seçme ve seçilme hakkı veren kanunun bir neticesi olarak, ikinci seçmen sayısına esas olacak nüfus "kadın - erkek" olarak tanımlanmıştır. Yapılan bir diğer önemli değişiklikle de ikinci seçmen sayıları yeniden düzenlenmiştir. Buna göre; "Bir bucak dahilinde bulunan kadın - erkek nüfustan her 400 kişi için 1 adet ikinci seçmen seçilecekti. Nüfus 400'ü geçtiğinde ise; 401 - 600 kişi için 1 müntehib-i sani; 601 - 1000 kişi için 2 müntehib-i sani; 1001-1400 kişi için 3 müntehib-i sani seçilecektir. Resmi Gazete, sayı 2891, 27 Aralık 1934 s. 4583.

${ }^{5}$ Cumhuriyet, 24 Mart 1939.

\section{Journal of History Studies}


üzerinde milletimizin takdir ve itimadını azami derecede toplayabilmiş olduğumuz kanaatindeyiz. ${ }^{6}$

Milletvekili seçimleri 26 Mart 1939'da gerçekleştirilmiştir. V. Dönemde 399 olan milletvekili sayısı bu dönemde 424'e yükselmiştir. Milletvekili sayısındaki artışın nedeni kurulan yeni iller (Bingöl, Bitlis, Hakkari, Rize ve Tunceli) ve nüfus sayısında meydana gelen yükselmedir. VI. Dönemde seçilen 424 milletvekilinden 420'si yukarıda ismi geçen CHP tarafından isimleri ilan edilmiş olan adaylardır. Partice aday gösterilmeyip, müstakil mebusluklar için boş bırakılan dört ilde münteb-i saniler, beşinci dönemde müstakil mebus olan ve bu dönemde de aday olan Berç Türker (Afyonkarahisar), Dr. Taptas (Ankara), İstamat Özdamar (Eskişehir), Dr. Abravaya Marmaralı (Niğde) seçilmişlerdir. VI. Devre için seçilen 424 milletvekilliğinden 290'1, V. Devrede de CHP'de milletvekilliği yapan kişilerdir. 4 müstakil mebusluk için seçilenler de V. Dönemde müstakil mebus olarak görev yapıyorlardı. VI. Devrede ilk kez milletvekili seçilenlerin sayısı 115'tir. Yani VI. Dönemde, yalnızca \%25'i diğer dönemlerde mebusluk yapmamış, yeni seçilmiş kişilerdir. ${ }^{7}$

\section{A. VI. Dönem TBMM Üyeleri Hakkında Bilgiler}

\section{Kadın Milletvekilleri}

1934 yılından önce yürürlükte bulunan anayasalarda ve seçim kanunlarında kadınlara yer verilmemekte, tüm düzenlemeler erkek nüfusuna göre yapılmaktaydı. 1924 Anayasası'nın ilk halinde "on sekiz yaşını ikmal eden her erkek Türk, mebusan intihabına iştirak etmek hakkını haizdir" hükmü yer alıyordu. ${ }^{8}$ Türk Demokrasisinin en büyük eksiklerinden olan kadınların siyasal hakları 1930 yılından itibaren tanınmaya başlanmıştır. Bu kapsamda 3 Nisan 1930 tarih ve 1580 sayılı Belediye Kanununun 20. maddesi ile kadınlara belediye seçimlerinde, belediye meclisine üye seçme ve seçilme hakk1 ${ }^{9} 26$ Ekim 1933 tarihinde, 442 sayılı Köy Kanununda yapılan değişiklikle de muhtarlık seçimlerinde seçme ve seçilme hakkı tanınmıştır. ${ }^{10} 1934$ yılında 1924 Anayasası'nın 10 ve 11. maddelerinde değişiklik yapılmıştır. Anayasası'nın 10. maddesinde yapılan değişiklikte "Yirmi iki yaşını bitiren kadın, erkek her Türk mebus seçmek hakkını haizdir" Anayasanın 11. maddesinde yapılan değişiklikte ise de "Otuz yaşını bitiren 2014 kadın, erkek her Türk mebus seçilebilir" ifadeleri yer almıştır. ${ }^{11}$ Ayrıca İntihab-1 Mebusan Kanunu'nda geçen "zükur(erkek)" ibareleri kaldırılarak yerine "kadın-erkek" ifadeleri konulmuştur. Böylece yapılan anayasa ve seçim kanunu değişiklikleriyle çoğulculuğun olmazsa olmazı olan siyasi haklarda kadın-erkek eşitliği sağlanmış oldu. ${ }^{12}$

\footnotetext{
${ }^{6}$ Cumhuriyet, 25 Mart 1939.

${ }^{7}$ Binark, age, s.61. ; Cemil Koçak, Türkiye'de Milli Şef Dönemi (1938-1945), Dönemin İç ve Dış Politikası Üzerine Bir Araştırma, Ankara, 1986, s.220'den Binark, age, s. 74.

${ }^{8}$ Ceride-i Resmiye, say1 71, 24 May1s 1340, s. 4.

${ }^{9}$ Resmi Gazete, say 1471,14 Nisan 1930, s. 8826.

3 Nisan 1930 tarih ve 1580 sayılı Belediye Kanununun 20. maddesi ile kadınlara belediye seçimlerine girme hakkı tanınmıştır. 26 Ekim 1933 tarihinde, 442 sayılı Köy Kanununda yapılan değişiklikle muhtarlık seçimlerine katılma hakkı tanınmıştır. 5 Aralık 1934 tarih ve 2599 sayılı kanun ile kadınlara milletvekili seçme ve seçilme hakkı da verilmiştir. Tuncer, age, s. 150.

10442 sayılı köy kanununun 20. maddesi aşağıdaki gibi değiştirilmiştir: "Her köyde bir köy derneği, bir koy muhtarı, bir de ihtiyar meclisi bulunur. Köyde 24 üncü maddeye göre köy muhtarını ve ihtiyar meclisi azalarını seçmeğe hakk olan kadın ve erkek köylülerin toplanmasına köy derneği derler. Köy muhtarı ve ihtiyar meclisi azaları doğrudan doğruya koy derneği tarafindan ve köylü kadın ve erkekler arasından seçilir. Köy muhtarı ihtiyar meclisinin başıdır" Resmi Gazete, sayı 2540, 28 Teşrin-i Evvel 1933, s. 3183.

${ }^{11}$ Resmi Gazete, say1 2877, 11 Kanunuevvel 1934, s. 4521.

${ }^{12}$ Resmi Gazete, say1 2877, 11 Kanunuevvel 1934, s. 4521.
} 
Kadınların milletvekili olarak TBMM'de ilk görev aldığı dönem V. Dönem olmuştur. 399 milletvekilinin $18^{\prime} \mathrm{i}$ kadınlardan oluşmaktadır. ${ }^{13}$ Toplam 424 üyeden oluşan VI. Dönem TBMM'de ise kadın milletvekili sayısı 16 'dır. ${ }^{14} \mathrm{~V}$. Dönemde 18 olan kadın milletvekili sayısı bu seçimlerde düşüş göstermiştir. VI. Dönem TBMM'de kadın milletvekili sayısının toplam milletvekili sayısına oranı $\% 3.77$ 'dir. ${ }^{15}$

Tablo 1: VI. Dönem TBMM'de Görev Yapan Kadın Milletvekillerinin Seçildikleri İller ve Meslekleri ${ }^{16}$

\begin{tabular}{|c|c|c|c|}
\hline Sira & Ad ve Soyad & Seçildiği İl & Mesleği \\
\hline 1 & Mebrure GÖNENÇ & Afyonkarahisar & Öğretmen \\
\hline 2 & Rukiye Belkis BAYKAN & Ankara & Öğretmen \\
\hline 3 & Saadet Türkan ÖRS & Antalya & Öğretmen \\
\hline 4 & Fatma MEMİK & Edirne & Doktor \\
\hline 5 & Nakiye ELGÜN & Erzurum & Öğretmen \\
\hline 6 & Fakihe ÖYMEN & İstanbul & Öğretmen \\
\hline 7 & Benal Zübeyde ARIMAN & İzmir & Öğretmen \\
\hline 8 & Şehime YUNUS & İzmir & Öğretmen \\
\hline 9 & Hacer DİCLE & Kastamonu & Öğretmen \\
\hline 10 & Mihri İffet PEKTAŞ & Malatya & Öğretmen \\
\hline 11 & Ayşe Sabiha GÖKÇÜL & Samsun & Öğretmen \\
\hline 12 & Ayşe Meliha ULAŞ & Samsun & Öğretmen \\
\hline 13 & Mümine Şemsa İŞCAN & Seyhan & Öğretmen \\
\hline
\end{tabular}

13 TBMM Albümü (1920-2010), ed: Sema Yıldırım, Behçet Kemal Zeynel, TBMM Basın ve Halkla İlişkiler Müdürlüğü ve Yayınları, Ankara, 2010, s. 239-299.

14 age, s. 304-363.

${ }^{15}$ Tuncer, age, s.150-151.

${ }^{16}$ TBMM Albümü (1920-2010), s. 304-363. 
Sibel Küçükkülahlı - Fatiih Özçelik

\begin{tabular}{|l|l|l|l|}
\hline $\mathbf{1 4}$ & Fatma Mergube GÜRLEYİ & Sivas & Belediye Azası \\
\hline $\mathbf{1 5}$ & Muammer DEVELİ & Tokat & Öğretmen \\
\hline $\mathbf{1 6}$ & Salise ABANOZOĞLU & Trabzon & Öğretmen \\
\hline
\end{tabular}

\section{VI. Dönem TBMM'de Görev Alan Milletvekillerinin Meslekleri}

VI. Dönemde seçilen milletvekillerinin meslekleri; hukuk, tıp, dişçi, veteriner, eczacı, mühendis, sivil bürokrat, asker, eğitimci, tüccar, çiftçi, bankacı, din görevlisi ve gazetecilerden oluşmaktadır. Meclisi oluşturan vekillerin çoğunluğunu hala önceki dönemlerde olduğu gibi askerler oluşturmaktadır. Ancak sayıda önceki dönemlere oranla bir düşüş görünmektedir. V. Dönemde asker oranı \%18 iken bu dönemde \%2'lik bir düşüş yaşanmıştır. Meclise hala ağırlıklı olarak resmi görevliler hakim durumdadır. Meclisteki çiftçilerin oranı ise \%6'y1 geçmemektedir. V. Dönemde $\% 8$ olan çiftçi sayıs1 da bu dönemde düşüş göstermiştir. Bankacıların oranında V. Döneme göre \%2'lik bir artış görülerek \%3 oranına ulaşılmıştır. Bir önceki döneme göre hukukçuların oranı $\% 1$, tıpçıların ve eğitimcilerin oranı $\% 2$ artmıştır. Tıpkı daha önceki dönemlerde olduğu gibi gelenek bozulmamış meclisin, çoğunluğunu yüksek öğrenim görmüş kesim oluşturmuştur. VI. Dönem TBMM'deki milletvekillerinin mesleki dağ $11 \mathrm{~m} ı$ ise rakamsal olarak şöyledir: ${ }^{17}$

\section{TABLO 2: VI. Dönem TBMM'nin Grafiksel Mesleki Yapısı}

History Studies

Volume 6 Issue 6

December 2014

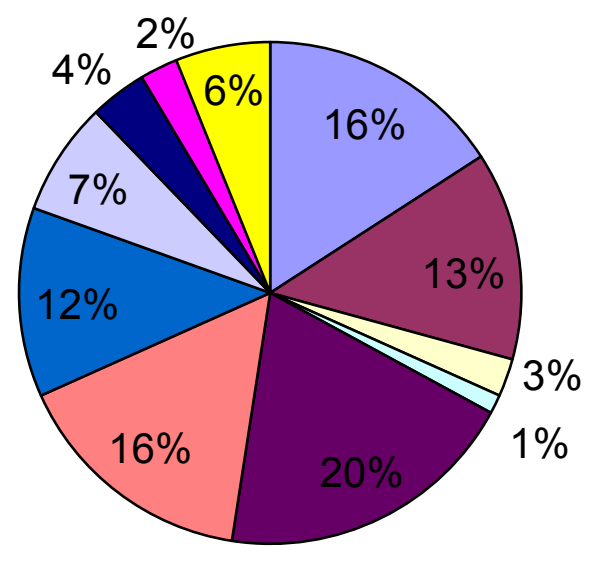

\begin{tabular}{|l}
$\square$ hukuk \\
$\square$ tıp \\
$\square$ Diş. Vet.Ecz \\
. Mühndislik \\
$\square$ asker \\
$\square$ eğitim \\
$\square$ ticaret
\end{tabular}

\section{VI. Dönem TBMM'de Görev Alan Milletvekillerinin Yaş Dağılımı}

VI. Dönem TBMM'deki milletvekillerinin çoğunluğu 44-58 yaş grubu içerisinde yer almaktadır. Bu da meclisin çok genç ve dinamik bir yapıya sahip olmadığını gösterir. Meclis yoğun olarak orta yaşlı milletvekillerinden oluşmaktadır. 29-33 yaş grubunun oranı ise $\% 0,5$ 'dir. Bu yaş grubundan sadece 2 milletvekili yer almaktadır. 38 - 34 yaş grubunun oranı

${ }^{17}$ Öz, age, s. 165 
bile \%3,81 gibi çok düşük bir düzeydedir. En yüksek oran \%20,4 ile 53 - 49 yaş arası gruba aittir. Bu grupta yer alan milletvekili sayıs1 86'dır.

TABLO 3: Milletvekillerinin Grafiksel Yaş Durumları

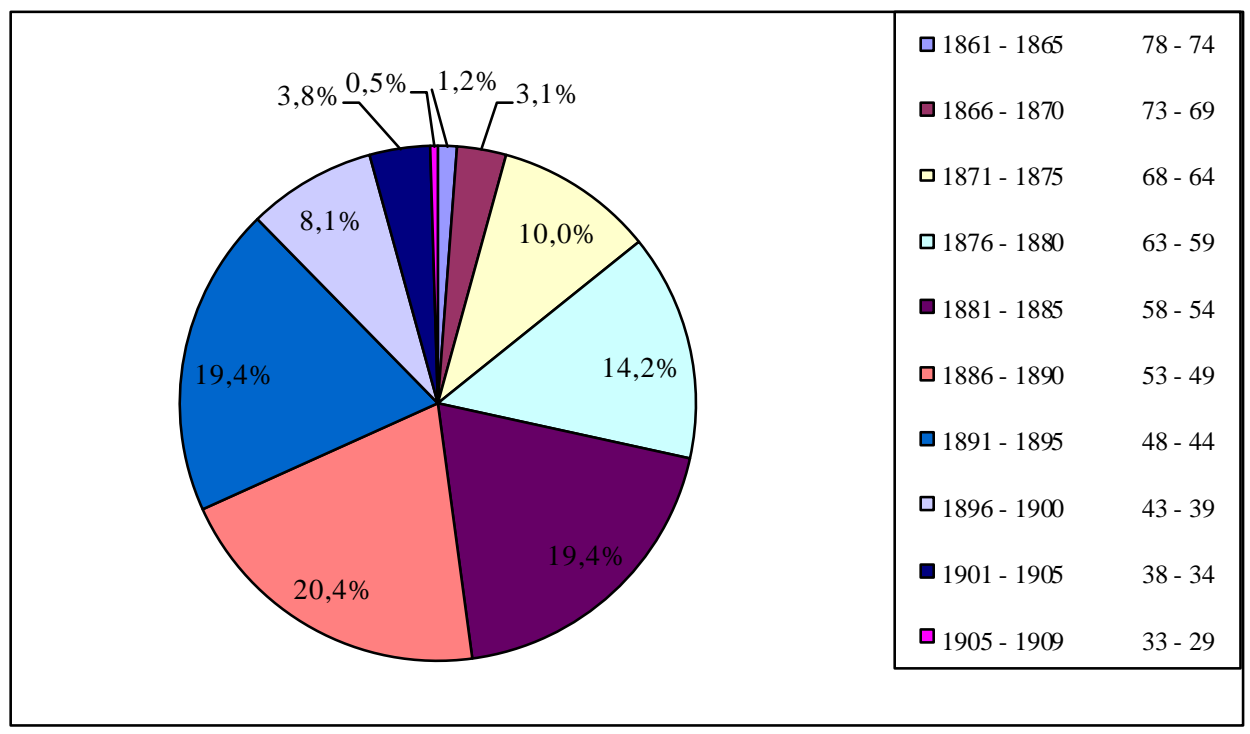

4. VI. Dönem TBMM'de Görev Alan Milletvekillerinin Bildikleri Yabancı Diller

VI. Dönem milletvekillerinin bildiği dil yoğun olarak Fransızca olmuştur. Osmanlı Devleti'nin son dönemlerinde yaşanan yoğun Fransız eğitiminin ve kültürünün etkisiyle bu dönemde en yüksek oranda konuşulan yabancı dil olarak Fransızca'yı görmekteyiz. Fransızca daha uzun yıllar mecliste en yüksek oranda bilinen dil olma özelliğini koruyacaktır. Bu dönemde Fransızca'dan sonra ikinci sırayı Almanca almıştır. İngilizce ise \%9'luk oranla ancak üçüncü sırada yer almaktadır. Yine bu dönemde Arapça, Farsça ve Rumca bilenlerin oranının da yüksek olduğunu görmekteyiz. ${ }^{18}$

TABLO 4: Milletvekillerinin Bildiği Dillerin Grafiksel Dağılımı

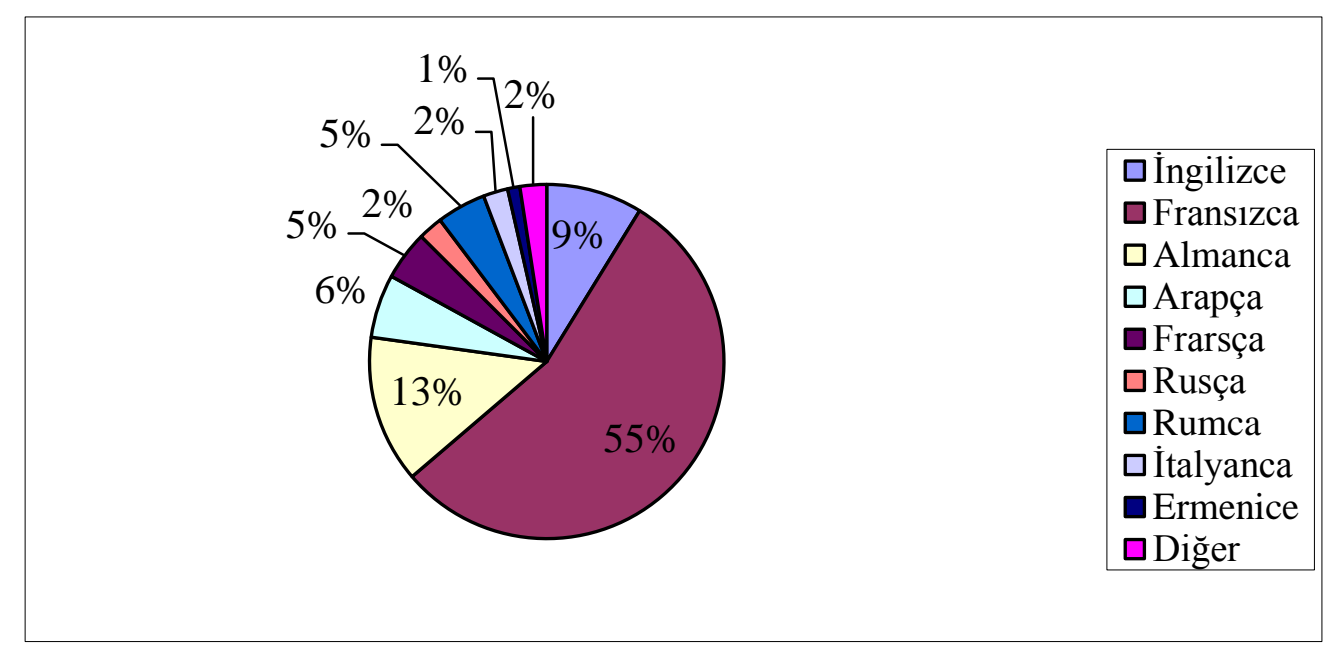

${ }^{18}$ age, s. $102-109$ 


\section{B. VI. Dönem TBMM'de Kurulan Hükümetler ve Politikaları}

CHP Parti Divanı Celal Bayar Hükümetinin istifa ettiği 25 Ocak günü TBMM seçiminin yenilenmesine karar vererek CHP Genel Sekreteri Refik Saydam'1 yeni hükümeti kurmakla görevlendirdi. Aynı gün Saydam Hükümetinin açıklandığı listedeki tek değișiklik Refik Saydam'dan boşalan Dahiliye Vekaletine Faik Öztrak'1n ve Ziraat vekaletine de Faik Kurtoğlu yerine Muhlis Erkmen'in getirilmiş olmasıdır. Hükümette yapılan bu isim değişikliklerine rağmen eski hükümet üyelerinin büyük ölçüde yerini koruması asıl değiştirilmek istenen ismin Celal Bayar olduğunun önemli bir göstergesidir. Bayar'ın yerine İnönü’nün her zaman en yakınında bulunan Refik saydam'ın atanmış olması beklenen bir gelişme idi. Saydam Hükümeti'nin kuruluşundan hemen sonra İnönü, ikamet ettiği Pembe Köşkten ayrılarak Çankaya'daki Cumhurbaşkanlığı Köşkü'ne taşınmıştır. Tüm siyasi otorite ve güç artık İnönü'nün elindedir. ${ }^{19}$

25 Ocak 1939 günü Meclis, yeni seçimlere gitme kararı almıştı. ${ }^{20}$ Şubat ayı ortalarında mebus adayı olmak isteyenlerin sayısı birkaç bine ulaşmış olup mart başında ise sayı 4500'ü aşmıştır. İstanbul'da mebus adayı sayısı ise $141^{\prime}$ dir. $^{21}$ Bütün yurtta 15 Mart 1939 Çarşamba günü başlayan ikinci müntehip seçimleri 21 Mart 1939 akşamı her tarafta sona ermiş ve bütün vatandaşlar oylarını Cumhuriyet Halk Partisi'nin gösterdiği adaylara vermişlerdi. Milletvekili aday listelerinin İsmet İnönü tarafından 24 Mart 1939 tarihinde ilan edildi ve aynı akşam radyolarda adayların isimleri okundu. Milletvekili seçimleri de 26 Mart 1939'da gerçekleştirildi. ${ }^{22}$

Büyük Millet Meclisi'nin çalışma ve faaliyetleri bir takım organlar ile yürütülmektedir. Bunlardan başlıcaları; düzenleme ve temsil organı (Başkanlık Divânı), tetkik ve ihzar organı, müzakere ve karar organı, idare ve inzibat organıdır. Meclisin, umûmî faaliyetini düzenlemede ve merasimde, Meclis'i temsil etmek üzere, bir Başkanlık Divânı (Riyaset Divânı) bulunmaktadır. Divân, geçici ve daimî olmak üzere iki şekilde düzenlenmiştir. Geçici başkanlık divânı, mebusların seçilmesini müteakip Meclis'in ilk toplantılarında ilk celse işlerini düzenlemek için toplanır. Esas itibariyle, en yaşlı bir mebusun başkanlığı altında en genç dört kâtipten meydana gelir. Bu divân mebusların yemin törenini ve Meclis'in daimî başkanlık divânının seçimini düzenledikten sonra çekilir. Daimî başkanlık divânı, bir başkan ile üç başkan vekilinden, altı kâtip ile üç idare âmirinden meydana gelir. Divânın başkan ve üyeleri, mebuslar arasından, bir sene için, gizli oylarla ve mutlak çoğunlukla seçilir. İlk oya müracaatta mutlak, yâni yarıdan bir fazla çoğunluk elde edilemezse, ikinci defa oylamaya başvurulur. Bu defa da adaylardan hiçbiri mutlak çoğunluk kazanmazsa, en çok oy almış olanlardan, seçimi matlûp adedin iki misli namzet ayrılarak bunlar hakkında, üçüncü ve son defa,oylama yapılır. En çok oy kazanmış olanlar seçilmiş olarak kabul edilir. Bu suretle divân oluşturulduktan sonra, Cumhurbaşkanlığı seçimine, seçim mazbatalarının tetkikine ve encümenlerin oluşturulmasına geçilir. ${ }^{23}$

Birinci Refik Saydam Hükümetinin yönetimi ve denetimi altında yapılan seçimler sonunda, VI. Dönem Büyük Millet Meclisi'ne 424 mebus seçilmiştir. Bu sayı Hatay'ın Anavatana katılmasıyla 429'a çıkmıştır. VI. Dönem Büyük Millet Meclisi ilk toplantısını 3 Nisan 1939 günü yapmıştır. Türkiye Büyük Millet Meclisi VI. Döneminin ilk oturumu en yaşlı üye olan Bilecik Milletvekili Dr. General Besim Ömer Akalın tarafından açılmıştır. Saat 14.00

\footnotetext{
${ }^{19}$ Cemil Koçak, Türkiye’de Milli Şef Dönemi (1938-1945), Cilt 2, İletişim Yayınevi, İstanbu 2003, s. 13-15.

${ }^{20}$ Binark, age, s.39.

${ }^{21}$ Tan Gazetesi 17.02.1939, 20.02.1939, 17.03.1939, 23.03.1939.

${ }^{22}$ Koçak, age, s. 30.

${ }^{23}$ Binark, age, s. 483.
} 
da başlayan oturum Meclis Başkanı ve riyaset Divanı üyelerinin seçimleriyle devam etmiştir. 408 oyla Çankırı milletvekili M. Abdülhalik Renda Meclis Başkanı seçilerek yeminini etmiştir. Riyaset Divanı'nın seçilmesinin ardından Cumhurbaşkanlığı seçimlerine geçilmiş, oylamaya katılan 413 kişinin evet oyuyla Ankara milletvekili İsmet İnönü Cumhurbaşkanı seçilmiştir. ${ }^{24}$

Cumhurbaşkanı İsmet İnönü yemininin ardından toplanan üçüncü celsede İstanbul milletvekili Refik Saydam'ı yeniden başvekilliğe atamıştır. Aynı celsede Refik Saydam'ın başkanlığında kurulan yeni İcra Vekilleri Heyeti'nin tasdik olunduğuna dair cumhurbaşkanı tezkeresi okunur. Refik saydam'ın önerisiyle İcra Vekilleri Heyeti'ne kabul edilenler okunur. Milletvekillerinin yeminlerinin ardından oturuma son verilir. ${ }^{25}$ Toplantıyı en yaşlı üye olan Dr. General Besim Ömer Akalın açmıştır. Mebusların yemin etmelerinden sonra Meclis Başkanlığına Çankırı Mebusu Mustafa Abdülhalik Renda getirilmiştir. Cumhurbaşkanlığına ise oybirliği ile Ankara Mebusu İsmet İnönü tekrar seçildi. Refik Saydam Hükümeti, yeni Meclis'in toplanması sebebiyle istifa etti. ${ }^{26}$

Cumhurbaşkanlığından gelen 3 Nisan 1939 tarihli tezkere ile Başbakanlığa tekrar Refik Saydam getirilmiş ve İcra vekilleri heyetini tespit ederek meclise teklif etmesi istenmiştir. Aynı gün yeni hükümetin İcra Vekilleri heyeti listesi Başbakan Refik Saydam tarafindan Cumhurbaşkanlığına sunulduktan sonra onaylanmıştır. ${ }^{27}$

\section{Refik Saydam Hükümeti ( 3 Nisan 1939 - 9 Temmuz 1942)}

Refik Saydam, Teşkilat-1 Esasiye Kanununun kırk dördüncü maddesine ve yine aynı kanunun kırk sekizinci maddesinde gösterilen Devlet Dairelerinin Vekaletlere ayrılması hakkındaki 3271 numaralı kanuna göre yeni İcra Vekilleri Heyetini şu şekilde oluşturmuştur: ${ }^{28}$

İCRA VEKILLERİ HEYETİ

$$
\begin{array}{ll}
\text { Başvekil } & \text { : Refik Saydam } \\
\text { Adliye Vekili } & \text { : Tevfanbul) } \\
\text { Adik Fikret Silay (Konya) }
\end{array}
$$

\footnotetext{
${ }^{24}$ TBMM Zabıt Ceridesi, VI. Devre, İçtima F, 1. İnikat, Cilt 1, 3 Nisan 1939 Pazartesi, Birinci Celse, s.2-3.

${ }^{25}$ TBMM Zabıt Ceridesi, VI. Devre, İçtima F, 1. İnikat, Cilt 1, 3 Nisan 1939 Pazartesi, Üçüncü Celse, s.4-5.

${ }^{26}$ age, s. 579.

${ }^{27}$ Resmi Gazete, Sayl: 4174, 4 Nisan 1939, (11515), s.1'den Binark, age, s. 578.

${ }^{28}$ TBMM Zabit Ceridesi, VI. Devre, İçtimâ E, İkinci İnikad, Cilt 1, 10 Nisan 1939, s. 5.
}

${ }^{29}$ Doktor Refik Saydam, 8 Eylül 1881 tarihinde İstanbul'da Fatih'te doğdu. Babası Çankırı'nın Çerkeş ilçesinin, Karacaviran nahiyesinin Dolap köyünden Uzunömeroğlu Abdurrahman Ağa'nın oğlu Hacı Ahmet Efendi'dir. Mahalle mektebini bitiren Dr. Refik saydam 1892 yılında Fatih Askeri Rüştiyesi'ne girdi. Buradan 1896'da Çengelköy Askeri Tıbbiye İdadisi'ne geçti. 22 Ekim 1905 tarihinde Askeri Tıbbiyeyi Doktor yüzbaşı olarak bitirdi. Almanya'da Berlin Askeri Tıp Akademisi'nde Brandenburg, Danzig, Spandou ve Scharite'te eğitim gördü. Balkan Savaşlarında ve Birinci Dünya Savaşında yaptığı çalışmalarla salgın hastalıklarla mücadele etti. Tifüse karşı hazırladığı aşı Tıp Literatürüne geçti ve I. Dünya Savaşında Alman ordusunda ve Kurtuluş Savaşı'nda kullanıldı. 1919 yılında 9. Kolordu sağlık müfettişi muavinliği görevi ile Mustafa Kemal'in yanında Samsun'a çıktı. Erzurum askeri hastanesine atanan Saydam, bu görevi kabul etmeyerek ordudan ayrılarak Erzurum ve Sivas kongresinin çalışmalarına katıldı. 1920'de TBMM'ye Doğu Beyazıt milletvekili olarak siyasi hayata başladı. Milletvekilliği görevinin yanında Milli Savunma Bakanlığı Sağlık Dairesi Başkanlığı görevini de yürüttü. İkinci dönemden başlayarak üyeliğini İstanbul milletvekili olarak sürdürdü. 10 Mart 1921 tarihinde Sağlık ve Sosyal Yardım (Sıhhat ve İçtimai Muavenet) bakanı seçildi.Türkiye Cumhuriyetinin ilk Sağlık Bakanı olan Refik Saydam 14 yıl boyunca bu görevini başarıyla sürdürerek sağlik hizmetlerinin temellerini attı. 1931-1938 yıllarında zaman zaman Eğitim ve Maliye Bakanlıklarına vekaleten eden Refik Saydam, Atatürk'ün ölümünden sonra İçişleri Bakanlığı, CHP genel sekreterliği ve 15 yıl süreyle de Kızılay Başkanlığı yaptı. 1939-1942 yılları arasında (11. ve 12. Hükümetlerde) Başbakanlık görevini sürdürdü. 8 Temmuz 1942' e İstanbul'un besin sorununun çözümlenmesi için yaptığı inceleme gezisinde kalp krizi geçirerek yaşamını yitirdi. Doktor Refik Saydam (1881-1942), Ölümünün Kırkıncı Yılı Anısına, Sağlık ve Sosyal Yardım Bakanlığı Yayınları, Ankara 1982, s. 7-14. 
Millî Müdafaa Vekili : [Gl.] Naci Tınaz (Bursa)

Dahiliye Vekili : Faik Öztrak (Tekirdağ)

Hariciye Vekili : : Şükrü Saraçoğlu (İzmir)

Maliye Vekili : Fuat Ağralı (Elâzı̆̆)

Maarif Vekili : Hasan Ali Yücel (İzmir)

Nâfıa Vekili : Ali Fuat Cebesoy (Konya)

İktisat Vekili : Hüsnü Çakır (Samsun)

Sıhhat ve İçtimaî Muavenet Vekili: Hulusi Alataş (Aydın)

Gümrük ve İnhisarlar Vekili : Ali Rana Tarhan (İstanbul)

Ziraat Vekili :Muhlis Erkmen (Kütahya)

Muhabere ve Münakale Vekili : Ali Çetinkaya (Afyonkarahisar)

Ticaret Vekili :Cezmi Ercin (Antalya)

10 Nisan 1939 tarihli oturumda VI. Dönem TBMM'nin çalışmaya başlaması münasebetiyle Hataylıların Büyük Millet Meclisi'ne olan bağl1lıklarılyla Türkiye'ye ve İnönü'ye bağlılıklarını bildiren telgrafları okunmuştur. ${ }^{30}$

Refik Saydam yeni kurduğu hükümetinin programını açıklamaya önceki dönemlerde izlenen Cumhuriyet Halk Partisi'nin programını uygulamaya devam edeceklerini söyleyerek başlamıştır. Bu dönemde önceki dönemlerden farklı olarak seneler geçtikçe vazifeleri daha da artan Nafia ve iktisat Vekaletlerinin birbirinden ayrıldığını duyurmuştur. Aynı biçimde ticaret ve sanayi işlerini gören İktisat Vekaletinin yalnızca sanayii ve maden işleriyle ilgili sorumlulukları bırakılırken, iç ve dış ticarete ait görevler Ticaret Vekaleti kurularak onun sorumluluğuna verilmiştir. Bakanlıkların da iş programlarını uygularken Cumhuriyet halk Fırkası'nın programından ayrılmayacaklarını vurgulamıştır. ${ }^{31}$

Saydam, denk bütçe esasına dayalı 1939-1940 bütçesinin milletvekillerine sunulduğunu ve bu bütçenin gayet başarılı bir plan olduğunu söyleyerek konuşmasını sürdürmüştür. Türkiye'nin dahili politikasının vatandaşlara huzur ve güven ortamı sunduğunu ifade ederek sürekli değişsen dış politikanın her zamankinden daha fazla tetikte olmayı gerektirdiğinin altını çizmiştir. İçinde bulundukları buhranlı yıllarda dünyada yaşanan tüm ani ve olumsuz değişimlere, felaketlere rağmen Türkiye'nin barışı korumak yolunda bütün devletlerle sürdürdüğü dostane tarafsızlık politikasını sürdürdüğünü; mevcut ittifaklarına ve barış sözleşmelerine bağl1lığının devam ettiğini söylemiştir. ${ }^{32}$ Hükümet programının okunmasının ardından milletvekillerinin de görüşleri alınmış ve oylamaya geçilmiştir. Oylamaya 424 üyeden 389'u katılmıştır. Oybirliği ile okunan hükümet programı kabul olunmuştur. ${ }^{33}$

II. Refik Saydam hükümetinin İcra Vekilleri Heyetinde sonradan bazı isim değişiklikleri yaşanmıştır. Adliye Vekiliğine Tevfîk Fikret Sılay'ın yerine, 26 Mayıs 1939'da Fethi Okyar, 12 Mart 1941'de de Hasan Menemencioğlu atanmıştır. Fethi Okyar, Adliye Vekilliği'nden sağlık nedenleriyle ayrıldıktan bir süre sonra, 7 Mayıs 1943 tarihinde ölmüştür. Ticaret

${ }^{30}$ TBMM Zabıt Ceridesi, VI. Devre, İçtimâ, F, İkinci İnikad, Cilt 1, 10 Nisan 1939, Birinci Oturum, s.12-13.

${ }^{31}$ TBMM Zabit Ceridesi, VI. Devre, İçtimâ, F, İkinci İnikad, Cilt 1, 10 Nisan 1939, İkinci Oturum, s.20.

32 İrfan Neziroğlu, Tuncer Yılmaz, T.B.M.M. Hükümetler - Programlarl ve Genel Kurul Görüşmeleri, Cilt:1 (24 Nisan 1920-22 Mayıs 1950), TBMM Basımevi, Ankara, 2013, s. 340-342.

${ }^{33}$ TBMM Zabıt Ceridesi, VI. Devre, İçtimâ, F, İkinci İnikad, Cilt 1, 10 Nisan 1939, İkinci Oturum, s.21-25. 
Vekilliğine Cezmi Erçin'in yerine 1 Kasım 1939'da Nazmi Topçuoğlu, 27 Kasım 1940'ta da Mümtaz Ökmen getirilmiştir. Gümrük ve İnhisarlar Vekilliğine Ali Râna Tarhan'ın yerine, 26 Mayıs 1939'da Râif Karadeniz; İktisat Vekilliğine Hüsnü Çakır'ın yerine 1 Ağustos 1941'de Sırrı Day; Dâhiliye Vekilliğine Faik Öztrak'ın yerine de 6 Mayıs 1942'de Fikri Tüzer atanmıştır. Millı̂ Müdafaa Vekiliğine Naci Tınaz'ın yerine 5 Nisan 1940'da Saffet Arıkan, 12 Kasım 1941'de de Ali Rıza Artunkal getirilmiştir. Muhabere ve Münakale Vekili Ali Çetinkaya'nın yerine 20 Kasım 1940'da Cevdet Kerim İncedayı; 12 Kasım 1941'de de Fahri Engin atanmıştır. ${ }^{34}$

\section{2. Şükrü Saraçoğlu Hükümeti (9 Temmuz 1942 - 9 Mart 1943)}

Başbakan Dr. Refik Saydam, Ticaret Bakanı Mümtaz Ökmen ile birlikte ekonomik sıkıntılara ait şikâyetleri incelemek üzere gittiği İstanbul gezisinde, 07.07.1942 gecesi kalp krizi geçirerek 61 yaşında vefat etmiştir. $\mathrm{Bu}$ üzücü ve beklenmedik olay üzerine cumhurbaşkanı İsmet İnönü, yeni hükümet kurulana kadar, Dahiliye vekili Dr. Fikri Tüzer'i vekaleten başbakan olarak görevlendirmiştir. İsmet İnönü 9 Temmuz 1942 tarihli riyaseti Cumhur tezkiresi ile İzmir Mebusu Şükrü Saraçoğlu ${ }^{35}$ nu başbakanlığa tayin ettiğini bildirmiştir. $^{36}$

\section{İCRA VEKÍLLERİ HEYETİ ${ }^{37}$}

\author{
Başbakan \\ Adliye Vekili \\ Millî Müdafaa Vekili
}

\author{
Şükrü Saraçoğlu (İzmir) \\ Hasan Menemencioğlu (Mardin)
}

Ali Riza Artunkal (Manisa)

\footnotetext{
${ }^{34}$ Binark, age, s. 583.

35 "Mehmet Şükrü Saracoğlu, 1886 (1302)'da İzmir-Ödemiş, Üçeylül Mahallesinde doğdu. Babası Saraç Mehmet Tevfik Usta, annesi Şerife Hanımdır. Ödemis Ilkokulunu ve Rüstiyesini bitirip 1906'da İzmir İdadisinden mezun oldu. Aynı yıl sınavla Mülkiye Okuluna girdi. Tatil aylarında Ödemiş'te Aşar Muharrirliği yaptı. 1909'da Mülkiye Mektebinden diploma aldı. Ayn yıl Aydın İli Maiyet Memurluğuna atandı. Maiyet memurluğu süresinin ilk yılında Aşar Muharrirliği ve özel ögrretmenlik yaptı. İkinci yılında muharrirliğini sürdürüp aynı zamanda İzmir Sultanisi matematik öğretmenliğini yürüttü. Bu sürede İdare Meclisi Müstantikliği görevini de üstlendi. 1912'de İzmir İttihat ve Terakki Ticaret Okulu Müdürlügüne getirildi. Bu görevde iken Ocak 1914'te burs alarak ögrenim için Belçika'ya gönderildi. Dört, beş ay sonra Genel Savaşın başlaması üzerine İmir'e döndü. Harbiyede yedek subay adayı olarak iki ay eğitim gördü. Mayıs 1915'te, ögrenimini tamamlaması için İzmir İli hesabına İsviçre'ye gönderildi. Cenevre Üniversitesi Siyasal ve İktisat bölümlerim bitirerek 1919 yazı sonunda yurda döndü. Öğrenciliği sırasında Cenevre Türk Talebe Cemiyetini kurdu ve başkanlığını yaptı. Dönüşünde doğduğu kasabanın Yunanlılar tarafindan işgal edildiğini öğrendi. Kuşadası'na gelerek Millî Harekâttaki yerini aldı. Bir süre sonra Nazilli'deki efeler cephesine katıldı. Bu sırada İzmir'den Meclisi Mebusan'a üye seçildi. İstanbul'a gönderildi. Meclisin dağılması üzerine yeniden dönüp çetelere katıldl. Millî ve düzenli ordunun kurulmasından soma Kuşadası'nda çiftlik kurmaya çalıştı. Burayı Yunanlıların işgal etmesi üzerine birkaç ay Milasve Külek taraflarına çekildi. Memleketin kurtuluşundan soma Kuşadası ve Ödemiş'e dönerek çiftçiliğini sürdürdü. Bu sırada TBMM'nin II. Dönem seçimlerine katıldl. 10 Temmuz 1923'te yapılan seçimde 807 oy olarak İzmir'den milletvekili seçildi. 11 Ağustos'ta Meclis'e katıldl, ertesi gün mazbatası onaylandi. Hariciye, Muvazene-i Maliye ve Ticaret komisyonlarında çalıştı. Hariciye Komisyonu Sözcülüğ̈̈ yaptı. 5 Aralık 1924'te Maarif Vekilliğine seçildi. Bir öncelik önergesi, Genel Kurulda milletvekili olarak 32 değişik konuda 94, Millî Eğitim Bakanı sıfatıyla 10 değişik konuda, 13 konuşması vardır. Şirketlerin yönetimi hakkında soru önergesi vermiştir. 1926'da Yunan Hükümeti Ille görüssmeleri yürüten Mübadele Komisyonunda Türk Heyetine Başkanlık etti. 2 Kasım 1927-27 Aralık 1930'da Maliye Bakanlı̆̆l, 4 Mayls 1931-1 Mart 1935'te Adliye, 1 Mart 1935-25 E k im 1937 ve 1 Kasım 1937-11 Kasim 1938'de Adliye, 11 Kasim 1938-25 Ocak 1939 ve 25 Ocak-3 Nisan 1939'da Hariciye Bakanlıklarında bulundu. 9 Temmuz 1942'de Başbakan oldu. 1 Kasım 1948-22 Mayls 1950'de TBMM Başkanlı̆̆ yapt. İzmir'den III, IV, V, V I I ve VIII inci dönemlerde de milletvekili seçilen Mehmet Şükrü Saraçoğlu, 1950'de politikadan çekildi. 27 Aralık 1953'te İstanbul'da öldü." Kazım Öztürk, Türk Parlamento Tarihi - TBMM II. Dönem (1923-1927), Cilt. 3, Türkiye Millet Meclisi Vakfi Yayınları, Ankara, 1995, s. 443-444.

${ }^{36}$ Binark, age, s. 594.

${ }^{37}$ TBMM Zabit Ceridesi, VI. Devre, İçtimâ 3, Yetmiş Altıncı İnikat, Cilt 27, 3 Ağustos 1942, s. 4.
} 


$\begin{array}{ll}\text { Dahiliye Vekili } & \text { Ali Fikri Tüzer (Erzurum) } \\ \text { Hariciye Vekili } & \text { Şükrü Saraçoğlu (İzmir) } \\ \text { Maliye Vekili } & \text { Fuat Ağralı (Elazığ) } \\ \text { Maarif Vekili } & \text { Hasan Ali Yücel (İzmir) } \\ \text { Nâfı Vekili } & \text { Ali Fuat Cebesoy (Konya) } \\ \text { İktisat Vekili } & \text { Sirrı Day (Trabzon) } \\ \text { Sihhat ve İçtimaî Muavenet Vekili } & \text { Hulusi Alataş (Aydın) } \\ \text { Gümrük ve İnhisarlar Vekili } & \text { Raif Karadeniz (Trabzon) } \\ \text { Ziraat Vekili } & \text { Şevket Raşit Hatipoğlu (Afyonkarahisar) } \\ \text { Münakalat Vekili } & \text { Fahri Engin (Samsun) } \\ \text { Ticaret Vekili } & \text { Behçet Uz (Denizli) }\end{array}$

$\mathrm{Bu}$ icra vekilleri Heyeti içerisinde iki isim değişikliği yaşanmıştır. Dahiliye Vekili ve Erzurum milletvekili olan Dr. Fikri Tüzer 16.08.1942 tarihinde vefat etmiş, yerine 17.08.1942 tarihinde Kütahya Mebusu Recep Peker atanmıştır. Bu tarihte Meclis toplantı halinde bulunmadığından, bu durum zabıt ceridesine kaydedilmemiştir. İkinci isim değişikliği ise Hariciye Vekilliğinde yaşanmıştır. Başbakan Şükrü Saraçoğlu'nun yürüttüğü Hariciye Vekilliğine 12.08.1942 tarihinde İstanbul Milletvekili Numan Menemencioğlu atanmıştır. ${ }^{38}$

Başbakanlığa atanan Şükrü Saraçoğlu, kurulan yeni hükümetin programını 05.08.1942'de millet meclisinde okumuştur. Yeni Hükümetin de daha önceki hükümetler gibi Cumhuriyet Halk Partisi programını hassasiyetle ve dikkatle uygulamaya çalışacağını belirterek konuşmasına başlayan Saraçoğlu, bir önceki Hükümet döneminde Vekilliğini yaptığı Dış İ̧̧leri ile ilgili konularda bilgi vererek devam etmiştir. Dünyanın savaş nedeniyle her geçen gün daha da karanlıklaşan manzarası içerisinde dış politikada daha önceki dönemlerde olduğu gibi Cumhurbaşkanı İsmet İnönü'nün uyguladığı politika doğrultusunda devam edileceğini belirtmiştir. "İnönü Türk Milletine, Türk Milleti de İnönü’ye çok yaraşıyor" dedikten sonra Milli Şef İnönü'nün etrafında Türk Milleti'nin bir bütün olduğunu vurgulamıştır. Bu dönemde gayretlerinin ülke topraklarını savaşın dışında tutmak olduğunu söylemiştir. Ancak bütün dikkat ve itinalarına rağmen istiklâl veya topraklar tecavüze mâruz kalacak olursa çarpışmaktan geri kalmayacaklarını da vurgulamıştır. ${ }^{39}$

Dış politika alanında Lozan'dan başlayarak faal ve olumlu bir siyaset izleyerek birçok sınavdan başarıyla geçtiğini ifade etmiştir. Sınırları dışında hiç bir sergüzeşt arkasında koşmayan Türkiye'nin savaşın dışında kalmak imkânlarını aradığını ve çözümü akıllı, olumlu bir tarafsılılı politikası uygulamakta bulduğunu söylemiştir. Türkiye'nin tarafsızlığı Politikasının kimseyi endişeye düşürmeyecek bir berraklığa ve samimiyete sahip olduğunu belirterek devletlerle önceki dönemde yapılmış anlaşmalar ve bunların devamlılığı konusunda nasıl bir yol izleneceği hakkında bilgi vermiştir. Önce İngiltere ile olan ittifak anlaşmasının her iki tarafın yararına olacak biçimde deva edeceğini belirterek, Türkiye ile Almanya arasındaki karş1lıklı anlayış ve dostluğu teşvik eden anlaşmanın da sürdürüleceğini vurgulamıştır. Savaşın

\footnotetext{
${ }^{38}$ Binark, age, s. 595.

${ }^{39}$ TBMM Zabıt Ceridesi, VI. Devre, İçtimâ 3, Yetmiş Yedinci İnikat, Cilt 27, 5 Ağustos 1942, s. 21.
} 
bu iki zıt kutbunda bulunan devletlerle olan müspet ilişkilerin Türkiye'nin tarafsızlık politikasının bir sonucu olduğunu vurgulamıştır. ${ }^{40}$

Şükrü Saraçoğlu programın iç politikayla ilgili açıklamalarına da öncelikli ve en önemli mesele olan iktisadi politika ile ilgili açıklamalar yaparak başlamıştır. O dönemde iktisadi problemlerin en önemlisi iaşe meselesidir. Başbakan açıklamasında, Liberal ekonomi politikalarının, insanların refahını arttırmak için her ülkede, o ülkede en bol ve en kolay yetişen ürünleri yetiştirmeyi ve bunları diğer memleketlerde en bol ve en kolay yetişen ürünlerle mübadele etmeyi önerdiğini belirterek eğer insanları yalnızca iktisat kaideleri idare edebilseydi aslında bu tavsiyeye uymak gerektiğini fakat bu ilmin yanında bir de hayatın kendi gerçeklerinin olduğunu söylemiştir. İşte bu gerçekler doğrultusunda eğer bir ülke, umumî ve geniş ihtiyaçlarını bizzat kendisi üretemiyorsa o ülkenin barışta ve savaşta yabancı ülkelerin boyunduruğunda kalabileceğini ve bu sebepten ötürü Türkiye'nin gıda, elbise, ayakkabı, silâh gibi umumî ve geniş ihtiyaçlarını bizzat kendi üretimiyle karşılamak için her firsattan faydalanarak çalışmak kararlılığında olduklarını belirtmiştir. ${ }^{41}$

Dönemin en önemli sorununun iaşe sorunu olduğunu, bunun da aslında geçici olduğunu ve savaş sonrasında böyle bir sorunun kalmayacağını belirtmiştir. Bütün dünyanın savaş içinde olduğunu ve üretimde çalışan yüz binlerce gencin silâhaltında bulunduğunu göz önünde tutan Hükümetin bu sorunu biraz da doğal bulduğunu çünkü bu dönemde savaşa en hazırlıklı ve en teşkilâtlı ülkelerde bile iaşe sıkıntısı facialar yaratacak hale geldiğini söylemiştir. Ülkede çekilen bu darlık, tüm dünyayı sarmış olan genel ve büyük ıstırabın bir parçasıdır. Saraçoğlu programının okunmasında bu darlığın çoğalması ihtimalinin de bulunduğunu belirtmiştir. Kendisinin de içerisinde yer aldığı bir önceki Saydam Hükümetinin, memlekette hayat pahalılığına ve iktisadi buhranlara engel olmak için birçok sert kararlar almış ve onları sıkı bir şekilde uygulamaya başlamıştır. Fakat günler geçtikce, bu kararların olumlu sonuçlar vermeyeceği, yapılan şikâyetlerle, tespit edilen fiyatlarla birçok malların ve gida maddelerinin bulunamamağa başlamasıyla ve yapılan tetkiklerle ortaya çıkmıştır. Bu sebepten yeni Hükümetin hemen işe başlayarak bu sert tedbirleri yumuşatmaya, bazılarını kaldırmaya ve bir kısmını değiştirmeğe karar verdiğini belirtmiştir. Tabi ki bu yolda fiyatlar, kendisiyle mal tedariki imkân haricinde çıkan resmi fiyatların doğal olarak üstüne çıkacak ve herhalde kara pazar fiyatlarının dununda kalacaktır. ${ }^{42}$

Hükümetin işe en önemli konu olarak gördüğü hububattan başladığını, ülkenin barış zamanında bile kendisine ancak yetebilen hububatı yetiştirdiğini ve pek az ihracat yaptığını ifade etmiştir. Savaşla birlikte ordunun buğday sarfiyatının yüz binlerce ton arttığı gibi ordunun hayvanları da arpa ve yulaf sarfiyatını yüz binlerce ton arttırdığını söylemiştir. Saraçoğlu, savaş başladığında Devletin elinde 250 bin tonluk buğday stokunun bulunduğunu, halkın ve tüccarın elindeki miktarın da yaklaşık olarak bu kadar olduğunu belirterek savaş yıllarına yaklaşık olarak 500 bin ton buğday stoku ile girildiğini açıklamıştır. Bu stok ülkeyi sadece iki yıl rahat yaşatabilmiştir. Üçüncü yıla girildiğinde artık buğday iaşesinde sıkıntılar yaşanmaya başlamıştır ve devlet İngiltere ile anlaşarak yaklaşı 100 bin tonluk bir buğday yardımı almıştır. Bu buğday alımının yapılmasına rağmen devlet yine de sert önlemler alarak buğday kullanımını denetim altına almaya çalışmışıır. ${ }^{43}$

\footnotetext{
${ }^{40}$ Neziroğlu, Yılmaz, age, s. 360.

${ }^{41}$ TBMM Zabit Ceridesi, VI. Devre, İçtimâ 3, Yetmiş Yedinci İnikat, Cilt 27, 5 Ağustos 1942, s. 22.

${ }^{42}$ TBMM Zabit Ceridesi, VI. Devre, İçtimâ 3, Yetmiş Yedinci İnikat, Cilt 27, 5 Ağustos 1942, s. 22. ; Neziroğlu, age, s. 361.

${ }^{43}$ TBMM Zabıt Ceridesi, VI. Devre, İçtimâ 3, Yetmiş Yedinci İnikat, Cilt 27, 5 Ağustos 1942, s. 22.
} 
Ekmeğin boyutlarının ve içerisindeki buğday miktarının düşürülmesi gibi tedbirler alınmasına rağmen yine buğday iaşesi konusundaki sıkıntılar tam anlamıyla bertaraf edilememiştir. Hububatlar içerisinde sadece buğdayda ülkenin yaklaşık olarak 250 bin tonluk bir açığının olduğu vurgulanarak, bu açığın giderilmesi için alınacak önlemleri sıralamıştır. Bu açığın ancak çiftçi memnun edilerek üretimin arttırılması, tüketimin azaltması ve dışarıdan buğday getirtilmesi yoluyla kapatılabileceği, hükümetin bu üç önlemi de aldığı belirtilmiştir. $\mathrm{Bu}$ doğrultuda dışarıdan buğday tedariki için özellikle Amerika'ya müracaat edildiğini, Amerikan Hükümeti'nin 45 gün içinde on beş bin ton buğdayı, nakil sırasında kullanılacak vasıtayı Türk Hükümetinin temin etmesi şartıyla tedarik etmeyi vaat ettiğini açıklamıştır. ${ }^{44}$

Arpa ve yulaf açığının bir kısmını dışarıdan temin etmekle birlikte farklı çözüm yolları da aranmıştır. Ülkede çok bol olan pancar ve pamuk çekirdeği küspelerinin önemli bir kısmını ordunun hayvanları için tahsis ederek bu açığın kapatılmasına çalışılmıştır. Fasulye, nohut, mercimek, pirinç gibi gıda mahsullerinin her biri kolaylıkla diğerinin yerine kullanılabilmesi, buğday politikası başarılı olduğu takdirde büyük miktarda bir bulgur mevcudunun bu maddelerin pahalılaşmasına mâni olabilmesi, yıllardır büyük miktarda fasulye ihraç eden bir ülke olunması ve o yıl bu maddelerin bol mahsul vereceğinin beklentisinin hâkim olması gibi sebeplerle bu mahsullerin üzerindeki kısıtlamalar hükümet tarafından kaldırılmıștır. Yine yağlar hakkında da benzer bir karar verilmiştir. Ülkede ihtiyacı karşılayan başlıca yağlar olan tereyağı, kuyrukyağı, pamukyağı, zeytinyağının aralarındaki fiyat farkı çoğaldığı zaman, bu maddelerden biri diğerinin yerine kullanılabilmektedir. Ülkenin o döneme kadar her yıl büyük miktarda zeytinyağı ihraç ettiği gibi önemli bir zeytinyağı stoğuna da sahip olduğu açıklanmıştır. Devletin elinin altında bulunan bu stokla ve ihracat yapılmak suretiyle yağ fiyatlarının anormal olarak yükselmesine mâni olmayı planladıklarını belirtmiştir. ${ }^{45}$

Ülkenin bir diğer önemli ihtiyacı olan pamuklu ve yünlü dokuma ihtiyacıyla ilgili de dönemin olağanüstü koşullarında önlem alma gereği doğmuştur. Ülkenin kumaş ihtiyacının küçük bir kısmı el tezgâhlan ile temin edilirken fabrikalar, yünlü kumaş ihtiyacının \% 80'ini, pamuklu kumaş ihtiyacının da \% 60'ını temin etmektedir. Üretilen bu iki cins kumaşta da Devlet fabrikalarının hisseleri \% 50'den biraz fazladır. Saraçoğlu, yünlü kumaş üretimindeki açıkta kalan bu \% 20 ve pamuklu kumaş ihtiyacında açıkta kalan bu \%40'ın kara pazarı yarattığını açıklamıştır. Kumaş buhranının önüne geçebilmek için ülke üretimini ülke ihtiyaçlarımız oranında arttırmak gerektiğini vurgulamıştır. Bunun içinde mevcut kumaş fabrikalarının üretim kapasitelerinin arttırlarak ve yeni fabrikalar açılmak suretiyle sorunun

Saraçoğlu Hükümeti döneminde devlet, 1939 yılında Toprak Mahsulleri Vergisi adıyla yeni bir vergiyi uygulamaya koyarak köylülerin yetiştirdiği ürünün \%10’una vergi olarak el koymuştur. Vergi, önce ölçme daha sonraki yıllarda ise tahmin usulüyle toplanmıştır. Ancak, memur yetersizliği, ölçme ve tahminde yapılan usulsüzlükler, depolama olanaklarının, ulaşım araçlarının, çuval sayılarının yetersizliği, verginin toplanmasından sorumlu olan Toprak Mahsulleri ofisinin yetersizliği ve yolsuzluklar nedeniyle verginin toplanmasında beklenen hedeflere ulaşamamıştır. Köylüler, “Aşar”ın geri dönüşü olarak yorumladıkları vergiden kaçmanın çeşitli yollarını bulmaya çalışmışlardır. Çok partili hayata geçildikten sonra, Cumhuriyet Halk Partisi'ne karşı Demokrat partiyi desteklemelerindeki en önemli sebeplerinden biri de hükümetin savaş yıllarında kırsal kesime yönelik uyguladığı bu politikalar olmuştur. Toprak Mahsulleri hakkında daha fazla bilgi için; Sibel Aloğlu, Toprak Mahsulleri Vergisi Kanunu ve Uygulamaları, (Abant İzzet Baysal Üniversitesi, Sosyal Bilimler Enstitüsü, Yayımlanmamış Yüksek Lisans Tezi), Bolu 2010.

${ }^{44}$ TBMM Zabıt Ceridesi, VI. Devre, İçtimâ 3, Yetmiş Yedinci İnikat, Cilt 27, 5 Ağustos 1942, s.22-23. Saraçoğlu konuşmanın devamında "Biz bir taraftan Amerika'nın gösterdiği yüksek anlayışa ve dostluğa derin teşekkürlerimizi ifa ederken diğer taraftan yabancı nakil vasıtası temini için çalışmağa başladık. Bundan maada vapur ve nakliye sıkıntılarımıza rağmen bir vapurumuzu ayrıca bu işe tahsis etmeğe çalışıyoruz.” demiştir. Savaş yılları boyunca Türkiye'nin önemli sorunlarından biri de ulaştırmadır. Bu konuda ayrıca bakınız; Murat Metinsoy, İkinci Dünya Savaşında Türkiye: Savaşve Gündelik Yaşam, Homer Kitabevi, İstanbul 2007.

${ }^{45}$ TBMM Zabıt Ceridesi, VI. Devre, İçtimâ 3, Yetmiş Yedinci İnikat, Cilt 27, 5 Ağustos 1942, s. 23. 
çözümüne çalışılacağı vaat edilmiştir. Ayrıca önceki yıllarda devlet fabrikaları hesabına çalışır bir hale getirilmiş olan özel pamuklu fabrikaları gibi özel yünlü dokuma fabrikalarının da devlet hesabına çalışır hale getirilmek istendiği söylenmiştir. Ülke dâhilinde bulunmasında ve yetiştirilmesine sıkıntı bulunmayan pamuk ve yünün alım fiyatlarının piyasa düzenine göre ayarlanmasına karar verilmiştir. Pamuk ve pamuk çekirdeğinin zaten tespit edilmiş fiyatları bulunduğunu, önce pamuk çekirdeğinin fiyatının serbest bırakılacağı, alınacak sonuçlara göre pamuğun da satış fiyatının serbest bırakılabileceğini ifade etmiştir. ${ }^{46}$

Saraçoğlu yaptı̆̆ 1 konuşmada zengin insanların zaten ekonomik bir sıkıntı içerisinde olmadıklarını, köylü ve çiftçinin de sadece bu malların satıcıları olduklarını; amele ve esnafların da günlük yevmiyelerini ve işlerini yeni şartlara daha önceden uydurdukları için geriye sorunlarını tek başına çözemeyecek tek bir grup kaldığını onların da memurlar olduğunu belirtmiştir. Hayat pahalılığının bütün ağırlığını özellikle belirli bir miktardan az maaş veya ücret alan memurların çektiğini, bunların sırtındaki yükü biraz hafifletmek için bu ailelerin reislerine bir başlangıç olmak üzere birer çift ayakkabı aynı biçimde yine aile reislerine ve eşlerine birer elbiselik kumaşı bedava olarak vermeyi taahhüt etmiş̧ir. Bundan başka bir de muhtaç vatandaşlara sosyal yardımlar yapılmaya çalışılacağı söylenmiştir. ${ }^{47}$

İpek ve ipekli dokuma ile diğer lüks eşyaların fiyatlarını serbest bırakılacağını ancak bunun yanında pancar gibi alıcısı tamamen Hükümet olan, şeker ve kömür gibi satıcısı tamamen Hükümet olan maddeler için ise alım ve satım işleri noktasında yapılması planlanan tek şeyin ahenkli ve ortalama birer fiyat tespitinden ibaret olacağı belirtilmiştir. Bunları tespit ederken göz önünde bulundurulacak en önemli unsurun ise iki taraftan birinin Devlet olduğu vurgulanmıştır. İthalat ve ihracatın ise toplumun istekleri ve ihtiyaçları doğrultusunda, adilane olarak yapılması ve bunların devlet tarafından gereken tedbirler alınarak düzenlenmesine karar verilmiştir. ${ }^{48}$

Konuşmasında "Biz Türküz, Türkçüyüz ve daima Türkçü kalacağız. Bizim için Türkçülük bir kan meselesi olduğu kadar ve laakal o kadar bir vicdan ve kültür meselesidir. Biz azalan ve azaltan Türkçü değil, çoğalan ve çoğaltan Türkçüyüz ve her vakit bu istikamette çalışacağız." demiştir. $^{49}$

Saraçoğlu, milliyetçilik duygularının ağır bastığı konuşmasında üniversitelerde ve yüksek okullarda okuyan öğrenci sayısının ve eğitim kalitesinin yükseldiğinden bahsederek, Köy Enstitülerinin sağlamış olduğu faydalara ve köylüler üzerindeki olumlu etkilerine değinmiştir. Köylüyü topraksız ve toprağı da köylüsüz bırakmayacaklarını belirtmiştir. İktisadi ve siyasi sahalarda Devletçilik, fertçilik ve kooperatifçiliğe geniş alanlar bırakıldığından bunlar arasında bir çıkar çatışmasının yaşanmayacağından bahsederek, bunun yaşanmaması için devlet olarak gereken tüm önlemlerin alınacağı vurgulanmıştır. Türk toplumlarında imtiyazlar ve toplumsal sınıfların asla mevcut olmadığını ve demokratik tutumun geçmişimizden beri artık yaşantımıza işlediğini söylemiştir. Tek Partili bir Devlet kurmuş olmayı halkçılık ilkesi temeline dayandıran Saraçoğlu, halkçılık ilkesine sıkı sıkıya bağlı kalınmaya devam edileceğini belirtmiştir. $^{50}$ Hükümet programının okunmasının ardından milletvekillerinin de görüşleri

${ }^{46}$ TBMM Zabıt Ceridesi, VI. Devre, İçtimâ 3, Yetmiş Yedinci İnikat, Cilt 27, 5 Ağustos 1942, s. 23-24.

${ }^{47}$ TBMM Zabıt Ceridesi, VI. Devre, İçtimâ 3, Yetmiş Yedinci İnikat, Cilt 27, 5 Ağustos 1942, s. 24.

${ }^{48}$ Neziroğlu, Y1lmaz, , age, s. 365.

${ }^{49}$ TBMM Zabıt Ceridesi, VI. Devre, İçtimâ 3, Yetmiş Yedinci İnikat, Cilt 27, 5 Ağustos 1942, s. 24-25.

${ }^{50}$ TBMM Zabıt Ceridesi, VI. Devre, İçtimâ 3, Yetmiş Yedinci İnikat, Cilt 27, 5 Ağustos 1942, s. 25. ; 
alınmış ve İcra Vekilleri heyeti için oylamaya geçilmiştir. Mecliste yapılan oylamaya 429 üyeden 381 'i katılmış ve heyet oybirliği ile onay almıştır. ${ }^{51}$

\section{Sonuç}

Makalenin amacına uygun olarak 1939 yılı genel seçimi, VI. Dönem milletvekillerinin genel durumu, bu dönem hükümetleri ve programları incelenmiş böylece Türkiye'nin bu dönemi aydınlatılmaya çalışılmıştır.

1939 seçimi tek partili dönemin daha önceki seçimlerinin bir tekrarı olmuştur. Bu seçimi öncekilerden farklı kılan ise Atatürk'ün ölümünden sonra yapılan ilk seçim olmasıdır. CHP'nin gösterdiği adaylar yine İntihab-1 Mebusan Kanun-1 Muvakkatı'ya göre iki aşamada gerçekleşen bir süreçte seçilmişlerdir. Ayrıca idari yapıda yeni illerin teşkilatlandırılması ve nüfusun artması gibi nedenlerin seçim sonunda milletvekili sayısının artışına yansıdığı görülmüştür. VI. Dönem milletvekillerini belirleyen 1939 seçiminde kadın vekillerin sayısının bir önceki V. Döneme göre, ki bu dönem kadınların ilk kez yer aldığı seçimdir, azaldığı görülmüştür. $\mathrm{Bu}$ tespit sosyolojik incelemeleri de gerektiren başka bir araştırmanın konusu olarak karşımıza çıkmıştır. Ayrıca bu kadın vekillerin tamamının kamu görevlisi olması, kamu görevlisi olmayan kadınların seçme ve seçilme hakkının kullanımı hakkında ne kadar bilinçli oldukları gibi bir sorgulamayı da beraberinde getirmektedir. Bu durum erkek vekillerin görevleri ve eğitim seviyeleri ile ilgili bir incelemede de kendini gösterecektir. Nitekim yukarıda verilen istatistiklerde de görüldüğü üzere VI. Dönem milletvekillerinin çoğunluğu yüksek eğitimli kişilerden oluşmaktadır. Bu durum ülkeyi yönetenlerin eğitim seviyesinin yüksek olması açısından bakıldığında nitelikli vekil algılamasını birlikte getirirken, 1939'da henüz sanayileşmemiş ve yeni rejimi henüz algılayamamış geniş halk kitlelerinin neden mecliste yer almadığ 1 ya da bunun o dönemin ve sonrasının şekillenmesinde nasıl bir etkiye sahip olduğu gibi soruları da akla getirmektedir. Şunu söylemek mümkündür ki iyi eğitim almış, yabancı dil bilen ve yaşlarına da baktığımız da deneyimli bir yaşam tecrübesine sahip olan VI. Dönem meclisin vekilleri en azından bir sonraki döneme kadar Türkiye'nin şekillenmesinde rol oynamışlardır.

VI. Dönem vekillerin seçiminden önce gerçekleşen hükümet değişikliğine baktığımızda istifa eden Celal Bayar Hükümeti'nin yerini alan Refik Saydam Hükümeti'nde yer alan devlet adamlarının isminin Celal Bayar'ınkilerle hemen hemen aynı olması dikkat çekicidir. Nitekim Refik Saydam hükümetin başı olunca onun yerine dahiliye vekaletine başka bir vekil atanmak zorunda kalmış bir de ziraat vekaletine farklı bir isim getirilmişti. Dolayısıyla bu durum alternatifi olamamasına rağmen değișen hükümetin bir önceki ile ne farkı olduğu ya da bir öncekinin neden tavsiye olunduğunu düşündürmektedir. Değişen isimler ve yerlerine gelen isimlere bakıldığında bunun siyasal bir manevra olduğu açıktır. Tek partili bir dönem olmasına karşın siyasal bir çekişme kişisel güç ve zaafların yönlendirici bir dinamik olabileceğini göstermektedir. Nihayet Refik Saydam Hükümeti seçime gitme kararı alarak VI.Dönem TBMM vekil adayları belirlenmiştir. Yapılan seçimde CHP'nin gösterdiği adaylar artık meşru olarak vekildir. Refik Saydam Hükümeti'nin gerçekleştirdiği seçimlerde 424 vekil mecliste yer almış Hatay'ın anavatana katılması ile bu sayı 429'a ulaşmıştır. VI.Dönem meclisi 3 Nisan 1939'da yaptığı ilk oturumda meclis başkanı ile Riyaset Divanı üyeleri seçimini gerçekleştirmiştir. Bunun ardından asıl önemli olan cumhurbaşkanlığ seçimidir ki sonucu şaşırtıcı olmayan seçimlerden biridir. Böylece İsmet İnönü cumhurbaşkanı seçilmiş ve 1939 seçimleri gerçekleştiren Refik Saydam'a tekrar hükümet kurma görevi verildi. Aynı gün Refik Saydam'in sunduğu icra vekilleri heyeti onaylanarak yeni hükümet kuruldu. Bu hükümet 3

${ }^{51}$ TBMM Zabıt Ceridesi, VI. Devre, İçtimâ 3, Yetmiş Yedinci İnikat, Cilt 27, 5 Ağustos 1942, s. 24-25-32. 
Nisan 1939-9 Temmuz 1942 tarihleri arasında görev yaptı. 10 Nisan 1939'da VI. Dönem TBMM çalışmaya başladı. Bu hükümet CHP'nin önceki programına bağlılığını belirtti ve Türkiye'de Nafia ile İktisat vekaletlerini ayrı ayrı teşkilatlandırdı. İktisat vekaletine yalnızca sanayi ve maden işleri verilirken iç ve dış ticaret için ticaret vekaleti kurulmuştur. Saydam Hükümeti 1939-1940 bütçesini açıkladıktan sonra iç politikanın tutarlı olduğu görüşüne binaen hareket ederek dış politikada da barışın korunmasına önem verdi. Refik Saydam'ın kalp krizi geçirerek ölmesi üzerine Şükrü Saraçoğlu hükümeti kuruldu.

Şükrü Saraçoğlu Hükümeti 9 Mart 1943'e kadar görev yaptı. Hükümet CHP'nin yönetim anlayış ve programına uygun olarak icraat yapılacağını Şükrü Saraçoğlu aracılığı ile açıklamış, Saraçoğlu İnönü'yü daha da ön plana çıkaran yaklaşımını daha baştan ifade etmişti. $\mathrm{Bu}$ durum İsmet İnönü'nün Türkiye Cumhuriyeti'ndeki siyasi hayatını şüphesiz daha da güçlendirdi. Saraçoğlu hükümetinin vurguladığı en önemli durum, savaşta Türkiye'nin durumunun ne olacağının ifade edilmesi idi. Nitekim Saraçoğlu; İnönü’nün bu konudaki politikasını vurgulayarak Türkiye topraklarını savaşın dışında tutmanın asıl amaç olduğunu yalnız bir saldırı olursa savunmadan geri kalınmayacağının da altını çizdi. Dolayısıyla bu hükümetin dış politikada en önemli sorunu da yaklaşan II.Dünya Savaşı oldu. İç politikada ise ekonomik sıkıntılar ve buna yönelik çözümler ile liberal ekonomi anlayışı önem kazandı. Liberal ekonomiyi anlatmak ve faydalarından bahsetmek hükümetin bu konudaki ilk icraatı olarak değerlendirilebilir. Dönemin en önemli sorunu olarak iaşe konusunda yaşanan sıkıntılar görünmektedir. Bu durum savaşla ilişkilendirilmiş ve hükümet savaş sebebinin ortadan kalkması ile bu problemin aşılacağı kanaatini taşıyordu. Önceki hükümetin bu konuda aldığı sert tedbirlerden bir sonuç çıkmadığı kanaatinde olan Saraçoğlu Hükümeti tedbirleri yumuşatma kararı aldı ve ülkenin hem sivil hem de askeri iaşesinde önemli rol oynayan hububat gibi bir üründe sıkıntıların önüne geçebilmek için Amerika ve İngiltere'den dış yardım aldı. Şüphesiz bu durum hükümetin dünya savaşındaki tarafsılılı politikasının diğer dünya ülkelerince nasıl algılandığı gibi başka bir araştırmanın konusu olabilecek bir soruyu da akla getirmektedir. Hububat, arpa, yulaf, pirinç gibi temel gıda ihtiyaçlarının üretiminin arttırılması ve tüketimin yönlendirilerek denetlenmesi gibi politikalar çözüm olarak görüldü. Pamuk ve yünlü üretimi için alınan tedbirlerden de anlaşılacağı gibi bu dönemde ülkenin iaşesi için önemli olan ürünlerle ilgili politikalara bakıldığında Saraçoğlu Hükümeti’nin vurguladığ liberal ekonominin önem kazanacağı açıklamasına rağmen devletleştirme eğilimi ortaya çıktı. $\mathrm{Bu}$ ekonomik darlıktan en çok etkilenecek grubun memurlar olduğunu düşünen hükümet, memurlara ve sosyal yardıma muhtaçlara yardımı önemsedi. Ülkenin iaşesi için gerekli olan ürünlerin ya da lüks tüketime giren ürünlerin iç ve diş ticaretteki durumunda devletçiliğin vurgulandığı görülmektedir. Bu hükümetin vurguladığı diğer önemli husus da Türkçülük oldu. nitekim Atatürk ilklerine bağlılı̆gını her firsatta dile getiren tek parti yönetimleri demokrasinin gereği olan çok partili hayata geçişi gerçekleştiremeyince söylemlerinde varlıklarını halka dayandırarak kendilerini meşrulaştırma çabası içinde olmuşlardır. Çalışmamızın konusu olan dönemde bu durum açıkça görülmektedir. 


\section{Kaynakça}

\section{Türkiye Büyük Millet Meclisi Zabıt Cerideleri}

TBMM Zabıt Ceridesi, 3 Nisan 1939, VI. Devre, İçtima F, Cilt 1.

TBMM Zabıt Ceridesi, 10 Nisan 1939, VI. Devre İçtimâ E, Cilt 1.

TBMM Zabut Ceridesi, 3 Ağustos 1942, VI. Devre, İçtimâ 3.

TBMM Zabıt Ceridesi, 5 Ağustos 1942, VI. Devre, İçtimâ 3.

\section{Resmi Gazete}

Resmi Gazete, say1 2891, 27 Aralık 1934.

Resmi Gazete, sayı 2540, 28 Teşrin-i Evvel 1933.

Resmi Gazete, sayı 2877, 11 Kanunuevvel 1934.

Resmi Gazete, Sayl: 4174, 4 Nisan 1939.

\section{Süreli Yayınlar}

Cumhuriyet, 24 Mart 1939.

Cumhuriyet, 25 Mart 1939.

Tan Gazetesi, 17.02.1939.

Tan Gazetesi, 20.02.1939.

Tan Gazetesi, 17.03.1939.

Tan Gazetesi, 23.03.1939.

\section{Kitaplar ve Makaleler}

BİNARK, İsmet, Türk Parlamento Tarihi (TBMM VI: Dönem 3 Nisan 1939 - 15 Ocak 1943), Türkiye Büyük Millet Meclisi Vakfi Yayınları, Ankara 2006.

Doktor Refik Saydam (1881-1942), Ölümünün Kırkıncı Yılı Anısına, Sağlık ve Sosyal Yardım Bakanlığı Yayınları, Ankara 1982.

KOÇAK, Cemil, Türkiye'de Milli Şef Dönemi (1938-1945), Dönemin İç ve Dış Politikası Üzerine Bir Araştırma, Ankara 1986.

Türkiye'de Milli Şef Dönemi (1938-1945), Cilt 2, İletişim Yayınevi, İstanbul, 2003.

METINSOY, Murat, İkinci Dünya Savaşında Türkiye: Savaş ve Gündelik Yaşam, Homer Kitabevi, İstanbul 2007.

NADİ, Yunus, "Baş makale", Cumhuriyet, 24 Mart 1939.

NEZIROĞLU, İrfan, YILMAZ Tuncer, T.B.M.M. Hükümetler - Programlart ve Genel Kurul Görüşmeleri, Cilt:1 (24 Nisan 1920-22 Mayıs 1950), TBMM Basımevi, Ankara, 2013.

ÖZ, Esat, Tek Parti Yönetimi ve Siyasal Katılım (1923-1945), Gündoğan Yayınevi, Ankara. 
ÖZTÜRK, Kazım, Türk Parlamento Tarihi - TBMM II. Dönem (1923-1927), Cilt. 3, Türkiye Millet Meclisi Vakfı Yayınları, Ankara 1995.

TBMM Albümü (1920-2010), ed: Sema Yıldırım, Behçet Kemal Zeynel, TBMM Basın ve Halkla İlişkiler Müdürlügü ve Yayınları, Ankara 2010.

TUNCER, Erol, Osmanlı'dan Günümüze Seçimler (1877 - 1999), Toplumsal Ekonomik Siyasal Araştırmalar Vakfi, Ankara 2002.

\section{Tezler}

ALOĞLU, Sibel, Toprak Mahsulleri Vergisi Kanunu ve Uygulamalarl, (Abant İzzet Baysal Üniversitesi, Sosyal Bilimler Enstitüsü, Yayımlanmamış Yüksek Lisans Tezi), Bolu 2010.

POLAT, Yüksel, XV. Dönem Türkiye Büyük Millet Meclisi(1973-1977), (Hacettepe Üniversitesi, Atatürk İlkeleri ve İnkılap Tarihi Enstitüsü, Yayımlanmamış Yüksek Lisans Tezi), İstanbul 2006.

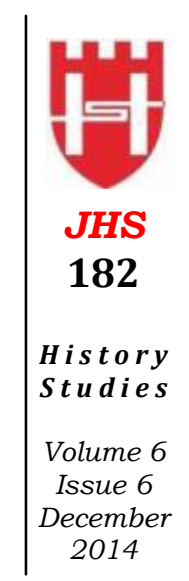

